\title{
Adjunctive Corticosteroids for COVID-19: A Retrospective Cohort Study
}

\section{Authors:}

Ooi Say Tat MD MPH ${ }^{1,5}$, Purnima Parthasarathy MBBS ${ }^{1}$, Lin Yi MBBS MSc ${ }^{5}$, Valliammai D/O Nallakaruppan MBBS MRCP MMed ${ }^{2}$, Shereen $\mathrm{Ng}$ Jia Huey MBBS MRCP MMed ${ }^{2}$, Tan Teck Choon MBBS MRCP FAMS ${ }^{3}$, Low Serena MBBS MSc ${ }^{6}$, Tang Terence MBBS MRCP 4

\section{Affiliation:}

1. Division of Infectious Diseases, Department of General Medicine, Khoo Teck Puat hospital, Singapore

2. Division of General Medicine, Department of General Medicine, Khoo Teck Puat hospital, Singapore

3. Division of Rheumatology, Department of General Medicine, Khoo Teck Puat hospital, Singapore

4. Department of Geriatric Medicine, Khoo Teck Puat hospital, Singapore

5. Clinical Epidemiology Unit, Khoo Teck Puat hospital, Singapore

6. Clinical Research Unit, Khoo Teck Puat hospital, Singapore

\section{Correspondence to:}

Dr. Ooi Say Tat, Division of Infectious Diseases, Department of General Medicine, Khoo Teck Puat hospital. 90 Yishun Central, Singapore 768828

Email: ooi.say.tat@ktph.com.sg 
medRxiv preprint doi: https://doi.org/10.1101/2020.07.18.20157008; this version posted July 21 , 2020. The copyright holder for this preprint (which was not certified by peer review) is the author/funder, who has granted medRxiv a license to display the preprint in perpetuity.

\section{$1 \quad$ ABSTRACT}

2

3 Background: Coronavirus disease 2019 (COVID-19) is associated with severe pneumonia, respiratory failure and death. We aim to evaluate the efficacy of adjunctive corticosteroids in

5 the management of COVID-19.

6

7 Methods: This is a retrospective cohort study of hospitalized adults ( $\geq 18$ years) who were diagnosed with COVID-19 and were given treatment. Treatment included

9 hydroxycholoroquine and lopinavir-ritonavir. Corticosteroids were included as adjunctive 10 therapy in mid-April, 2020. We compared composite outcomes of clinical progression and 11 invasive mechanical ventilation (MV) or death between group that received treatment only

12 (Group A) versus group that received adjunctive corticosteroids (Group B). Entropy balancing was used to generate stabilized weight for covariates between treatment groups. Unweighted Kaplan-Meir curves, weighted and adjusted Cox regression analysis were used to estimate effect of adjunctive corticosteroids on composite outcomes. Subgroup analysis was performed on those with pneumonia.

Results: Of 1046 patients with COVID-19, 57 received treatment alone (Group A) and 35 received adjunctive corticosteroids in addition to treatment (Group B). Median day of illness at treatment initiation was 5 day. There were 44 patients with pneumonia; $68.9 \%$ of them were not requiring supplemental oxygen at treatment initiation. Overall, 17 (18.5\%) of 92 patients had clinical progression including $13(22.8 \%)$ of 57 patients in Group A versus 4 (11.4\%) of 35 patients in Group B ( $p=0.172)$. Unweighted Kaplan-Meier estimates showed no significant difference in the proportion of patients who had clinical progression or invasive $\mathrm{MV}$ or death between the 2 treatment groups. However in those with pneumonia, there were lower proportions of patients in Group B with clinical progression $(11.1 \%, 95 \% \mathrm{Cl} 0.0-22.2$ versus $58.8 \%, 95 \% \mathrm{Cl} 27.3-76.7$, log rank $p<0.001)$; and invasive MV or death $(11.3 \%$, 
medRxiv preprint doi: https://doi.org/10.1101/2020.07.18.20157008; this version posted July 21,2020 . The copyright holder for this preprint (which was not certified by peer review) is the author/funder, who has granted medRxiv a license to display the preprint in perpetuity.

It is made available under a CC-BY-NC-ND 4.0 International license .

adjusted cox regression analysis, patients in Group B were less likely to have clinical progression, (adjusted HR [aHR] 0.08, 95\% Cl 0.01-0.99, p=0.049) but there was no statistical significant difference in risk of requiring invasive MV or death $(a \mathrm{HR} 0.22,95 \% \mathrm{Cl}$ $0.02-2.54, p=0.22)$. In subgroup with pneumonia, patients in Group B were significantly at lower risk of clinical progression (aHR $0.15,95 \% \mathrm{Cl} 0.06-0.39, \mathrm{p}<0.001)$ and requiring invasive MV compared to Group A (aHR 0.30, 0.10-0.87, p=0.029).

Conclusions: Use of adjunctive corticosteroids is associated with lower risk of clinical progression and invasive MV or death, especially in those with pneumonia. Concurrent use of antivirals and corticosteroids should be considered in the management of COVID-19 related pneumonia.

Keywords: COVID-19, corticosteroids, hydroxychloroquine

\section{INTRODUCTION}

44 Coronavirus disease 2019 (COVID-19) emerged in Wuhan city, China in December

452019 and has since evolved to a worldwide pandemic. Its clinical features range from asymptomatic to severe pneumonia requiring invasive mechanical ventilation and death..$^{1,2,3}$

Severe disease is typically marked by rapid clinical deterioration with features of hyperinflammation. ${ }^{4,5}$

51 Considering its pathophysiology, use of immunomodulatory agent and corticosteroids have been proposed. ${ }^{6}$ Recent studies on use of tocilizumab and dexamethasone have shown promising results in reducing mortality in severe 
medRxiv preprint doi: https://doi.org/10.1101/2020.07.18.20157008; this version posted July 21,2020 . The copyright holder for this preprint (which was not certified by peer review) is the author/funder, who has granted medRxiv a license to display the preprint in perpetuity.

It is made available under a CC-BY-NC-ND 4.0 International license

54 disease. ${ }^{7,8}$ However, treatment approach for early infection to prevent clinical

progression to severe disease remains unclear.

56

57 At our center, decision to treat and treatment selection have evolved over time. It

58 included interferon beta, lopinavir/ritonavir, hydroxycholoroquine (HCQ).

59 Prednisolone and tocilizumab were included as part of the treatment for COVID-19 in mid-April 2020 when there was reported hyperinflammation related to COVID-19

61 and use of anti-inflammatory agent might improve clinical outcome. ${ }^{9,10,11,12}$ We aim

62 to evaluate the effect of adjunctive corticosteroids in the management of COVID-19.

63

METHODS

Study design and participants

This is a retrospective, observational cohort study of patients with COVID-19

admitted to our hospital from February 9, 2020 to May 31, 2020.Data was retrieved

from electronic medical records and included basic demographics, comorbidities, laboratory investigations and medications administered.

We included adults ( $\geq 18$ years) with COVID-19, confirmed by PCR on

nasopharyngeal swab who were admitted to our center and received treatment for

COVID-19. Those who were on supportive care only, on invasive mechanical

ventilation prior to treatment or those admissions not related to respiratory illness were excluded. 
medRxiv preprint doi: https://doi.org/10.1101/2020.07.18.20157008; this version posted July 21, 2020. The copyright holder for this preprint

\section{Treatment}

80 Decision to start treatment was at discretion of the treating physicians in consultation

81 with an Infectious Diseases physician. Treatment regimen included lopinavir/ritonavir

$82400 / 100 \mathrm{mg}$ twice a day, hydroxychloroquine 400mg twice on day 1 , followed by

$83200 \mathrm{mg}$ three times a day on days 2-5 and prednisolone. Dose of prednisolone varied

84 from $30 \mathrm{mg}$ once a day to $40 \mathrm{mg}$ twice a day at the physician's discretion depending

85 on severity of illness and patient's body weight. Corticosteroids use of 3 days or more for any medical indications was considered as adjunctive corticosteroids.

88 Patients were classified into 2 groups, group that received usual treatment without corticosteroids (Group A) and group that received adjunctive corticosteroids in addition to usual treatment (Group B). Clinical conditions of the patients with COVID19 included at initiation of treatment were categorized into 3 stages: COVID-19 without pneumonia (Stage 1), COVID-19 related pneumonia not requiring supplemental oxygen (Stage 2) and COVID-19 related pneumonia requiring supplemental oxygen (Stage 3). Chest radiograph was the primary modality used in the assessment for pneumonia in our cohort.

\section{Outcomes:}

98 Primary outcome was a composite of clinical progression or death. Clinical progression is defined as progression to requirement of supplemental oxygen in Stage 1 and 2 or progression to invasive mechanical ventilation in any stage whichever is earlier. Secondary outcome was a composite of invasive mechanical ventilation or death. 
medRxiv preprint doi: https://doi.org/10.1101/2020.07.18.20157008; this version posted July 21,2020 . The copyright holder for this preprint (which was not certified by peer review) is the author/funder, who has granted medRxiv a license to display the preprint in perpetuity. It is made available under a CC-BY-NC-ND 4.0 International license .

104 Subgroup analysis was performed on those with pneumonia (Stage 2 \& 3)

105

106 Statistical analysis:

107 Categorical variables are shown as numbers and percentages while continuous

108 variables as median with interquartile range (IQR). Comparison of continuous and categorical data between groups was done using Mann-Whitney $U$ test and $X 2$ test or Fisher's exact test as appropriate.

112 Magnitude of changes in C-reactive protein (CRP) level following initiation of

113 treatment were calculated using available CRP values compared to baseline CRP

114 (delta CRP). Median values of delta CRP and daily maximum temperature following

115 initiation of treatment up to 14 days were plotted by treatment group for comparison.

117 Data was preprocessed with entropy balancing to achieve covariate balance

118 between the two treatment groups to reduce model dependence for the subsequent estimation of treatment effects. ${ }^{13}$ Weight derived from maximum entropy reweighting scheme was used to generate stabilized weight for each subject in the treatment

121 groups. Balanced covariate is defined by standardized mean difference of less than

1220.1 and variance ratio between $0.5-2.0$. Procedure of covariate balance was

123 performed separately for all eligible subjects and in subgroup with pneumonia.

124 Baseline covariates used to assess balanced weighting between treatment groups

125 were age, gender, body mass index (BMI), comorbidity, clinical stage, antibiotic use,

$126 \mathrm{CRP}$, procalcitonin, lymphocyte count, neutrophils-lymphocyte ratio and creatinine. 
medRxiv preprint doi: https://doi.org/10.1101/2020.07.18.20157008; this version posted July 21,2020 . The copyright holder for this preprint (which was not certified by peer review) is the author/funder, who has granted medRxiv a license to display the preprint in perpetuity.

It is made available under a CC-BY-NC-ND 4.0 International license.

128 Figure 2 displays the standardized mean difference of overall cohort subjects and subgroup with pneumonia between the two treatment groups. Imbalanced covariates

130 between the two treatment groups were age, procalcitonin and creatinine. In

131 subgroup with pneumonia, age, procalcitonin, creatinine and neutrophil-lymphocyte 132 ratio were imbalanced (Table S1).

133

134 Missing data of covariates were mainly limited to CRP and procalcitonin $(1.1 \%)$.

135 Multiple imputation was applied for missing data.

137 Kaplan Meier curves and cox regression analysis were used to compare time to composite outcomes between 2 treatment groups. Patients without primary end-point event were censored on date of discharge. Proportions of patients with composite outcomes between 2 treatment groups were compared using unweighted KaplanMeier estimates. We used weighted Cox proportional-hazards regression models with adjustment for imbalanced covariates to estimate effect of adjunctive corticosteroids on composite outcomes. The effect estimate is shown using hazard ratio $(\mathrm{HR})$ with $95 \%$ confidence interval $(95 \% \mathrm{Cl})$.

146 We considered two-sided $p$ value test of less than 0.05 as statistically significant.

147 Comparison of baseline characteristics by treatment group, patterns of fever and 148 CRP changes following treatment was performed using STATA version 15 (STATA 149 Corp., Texas, USA). Multiple imputation, entropy balancing with covariate balance assessment and Cox regression analyses were performed using $\mathrm{R}$ Statistical

151 Software (Foundation for Statistical Computing, Vienna, Austria) and related R 152 packages (MICE, Weighlt, ebal and Cobalt). ${ }^{14,15}$ 
medRxiv preprint doi: https://doi.org/10.1101/2020.07.18.20157008; this version posted July 21, 2020. The copyright holder for this preprint (which was not certified by peer review) is the author/funder, who has granted medRxiv a license to display the preprint in perpetuity.

154 RESULTS

155 Between February 9, 2020 and May 31, 2020, there were 1046 patients with covid-

15619 admitted to our hospital. Of these, 94 (9.0\%) patients received treatment. Two

157 patients were excluded as treatment was started following invasive mechanical

158 ventilation. In total, 57 patients received treatment without corticosteroids (Group A)

159 and 35 patients received adjunctive prednisolone to treatment (Group B). (Figure 1)

160

161 Median number of days of illness at the start of treatment was 4 days and 5 days in

162 Group A and B respectively. Duration of HCQ used was 7 days (IQR 5-7) in Group A and 5 days (IQR 5-7) in Group B.

164 Prednisolone use was 5 days (IQR 3-7).

165

166 There were 44 patients in the cohort who had pneumonia. Of these, $68.9 \%$ of them

167 were not requiring supplemental oxygen at treatment initiation. Between the 2

168 groups, there were higher proportions of patients in Group B who had pneumonia

169 and requiring supplemental oxygen, use of antibiotics and higher CRP level at

170 initiation of treatment (Table 1). Eight subjects received tocilizumab in our cohort. All

171 were given post mechanical ventilation except 2 cases (one in each treatment

172 group).

173

174 Following treatment initiation, body temperature of patients trended down in similar

175 pattern between the 2 treatment groups. CRP in Group B trended down. However, in

176 Group A, it trended up at around 5-8 days following treatment before declining

177 (Figure 3). 
medRxiv preprint doi: https://doi.org/10.1101/2020.07.18.20157008; this version posted July 21, 2020. The copyright holder for this preprint (which was not certified by peer review) is the author/funder, who has granted medRxiv a license to display the preprint in perpetuity.

179 Overall, $17(18.5 \%)$ of 92 patients had clinical progression including $13(22.8 \%)$ of 57

180 patients in Group A versus 4 (11.4\%) of 35 patients in Group B ( $p=0.172)$ (Table S2

181 in supplementary material).

182 There were 11 patients required invasive mechanical ventilation; 7 (12.2\%) patients

183 in Group A and 4 (11.4\%) patients in Group B. One death occurred in Group A

184 following invasive mechanical ventilation and none in Group B.

185

186 Unweighted Kaplan-Meier estimates showed no significant difference in the

187 proportion of patients who had clinical progression or invasive mechanical ventilation between the 2 treatment groups (Figure 4). At day 12 after treatment initiation, the proportion of patients with clinical progression was $23.3 \%(95 \% \mathrm{Cl} 11.3-33.7)$ in

191 (95\% Cl 3.3. - 20.4) of patients in Group A required invasive mechanical ventilation

192 versus $12.2 \%(95 \%$ Cl $0.2-22.7)$ of patients in Group B (log rank $p=0.85)$. However,

193 in subgroup analysis of those with pneumonia, there was beneficial effect of

194 adjunctive prednisolone compared to treatment alone. At day 12 after treatment

195 initiation, the proportion of patients with clinical progression was $58.8 \%(95 \% \mathrm{Cl} 27.3$

196 - 76.7) in Group A versus 11.1\% (95\% Cl 0.0 - 22.2) in Group B (log rank p<0.001);

$19741.2 \%(95 \% \mathrm{Cl} 12.4$ - 60.5$)$ of patients in Group A required invasive mechanical 198 ventilation versus $11.3 \%(95 \%$ Cl $0.0-22.5)$ of patients in Group B (log rank $p=0.016)$.

201 In unadjusted cox regression, there was no significant difference in risk of clinical 202 progression between the two treatment groups (Table 3). In weighted and adjusted 
medRxiv preprint doi: https://doi.org/10.1101/2020.07.18.20157008; this version posted July 21,2020 . The copyright holder for this preprint (which was not certified by peer review) is the author/funder, who has granted medRxiv a license to display the preprint in perpetuity.

It is made available under a CC-BY-NC-ND 4.0 International license .

cox regression analysis, patients in Group B were less likely to have composite requiring invasive mechanical ventilation or death $(\mathrm{aHR} 0.22,95 \% \mathrm{Cl} 0.02-2.54$, $p=0.22)$. In subgroup analysis of those with pneumonia, patients in Group B were significantly at lower risk of clinical progression (aHR $0.15,95 \% \mathrm{Cl} 0.06-0.39$, $p<0.001)$ and requiring invasive mechanical ventilation compared to Group A (aHR

$0.30,0.10-0.87, p=0.029)$.

\section{DISCUSSION}

Severe acute respiratory syndrome coronavirus 2 (SARS-Cov-2) infection is characterized by high viral replication during the initial phase of illness and a robust hyper immune response leading to morbidity and mortality. ${ }^{9,10,16}$ Our study provides important insights into the management of early COVID-19-related pneumonia, particularly highlighting the need to address both the viral replication and the inflammatory response in the early stages of infection.

Our cohort of patients either received antiviral alone (mostly $\mathrm{HCQ}$ ) or were treated with a combination of $\mathrm{HCQ}$ and corticosteroids (Prednisolone) during the early phase

222 of illness. The use of adjunctive prednisolone along with HCQ was associated with a significantly lowered risk of clinical disease progression, especially in those with pneumonia. $68.9 \%$ of patients with pneumonia in our cohort were not on supplemental oxygen at initiation of treatment. Early use of prednisolone in our patients with COVID-19 pneumonia and not on supplemental oxygen, had a $70 \%$

227 lower risk of progressing to invasive mechanical ventilation or death compared to 
medRxiv preprint doi: https://doi.org/10.1101/2020.07.18.20157008; this version posted July 21,2020 . The copyright holder for this preprint (which was not certified by peer review) is the author/funder, who has granted medRxiv a license to display the preprint in perpetuity. It is made available under a CC-BY-NC-ND 4.0 International license .

non-steroid group-(HR 0.30, 95\% Cl $0.10-0.87)$. The duration of prednisolone use in

232 Emerging data have shown benefits of anti-inflammatory agents in the management of severe COVID-19 pneumonia, especially with the use of tocilizumab and corticosteroids..$^{7,8}$ The RECOVERY trial involving the use of dexamethasone in hospitalized patients with COVID-19 in UK showed a $20 \%-40 \%$ reduction in mortality in those with pneumonia requiring oxygen and invasive mechanical ventilation. However, there was a trend towards increased mortality when corticosteroids were used in patients not receiving respiratory support at randomization. ${ }^{8}$ This seems to correspond to use of corticosteroids in early pneumonia. Earlier observations of adverse outcomes with corticosteroids use in SARS and Middle East respiratory syndrome (MERS-CoV) infections may explain the undesired consequences of corticosteroids in early phase of COVID-19 pneumonia at which virus replication is active. ${ }^{17}$

HCQ has been shown to effectively inhibit SARS-CoV-2 infection in vitro. ${ }^{18}$ Despite its in-vitro activity, clinical efficacy of HCQ has largely been reported as ineffective.

247 The RECOVERY trial reported an increased risk of invasive mechanical ventilation

248 or death with use of HCQ compared to supportive care. ${ }^{19} \mathrm{We}$ found that the group on treatment with antivirals without adjunctive corticosteroids in our cohort had a more protracted course with a higher inflammatory response. Their CRP trended to

251 higher level at day 5-8 post treatment despite a similar fever response in both

252 groups. Perhaps this is a paradoxical inflammatory reaction due to treatment. We 
medRxiv preprint doi: https://doi.org/10.1101/2020.07.18.20157008; this version posted July 21,2020 . The copyright holder for this preprint (which was not certified by peer review) is the author/funder, who has granted medRxiv a license to display the preprint in perpetuity.

It is made available under a CC-BY-NC-ND 4.0 International license .

253

254

255

256

257

258

259

260

261

262

263

264 The prominent protective effect of adjunctive prednisolone observed in our cohort

265

271 covariates and confounders.

might draw simile to post-treatment inflammatory response in pneumocystis jiroveci pneumonia, where early adjunctive corticosteroids could decrease risk of respiratory failure. ${ }^{20}$

The use of prednisolone during early pneumonia in our study had a significantly better outcome which may be due to the concurrent administration of antiviral agents such as HCQ or lopinavir/ritonavir. A similar observation could be from a retrospective study that showed significant lower risk of invasive mechanical ventilation or death with the use of tocilizumab to standard care that included HCQ and lopinavir/ritonavir in the first week of COVID-19 pneumonia. ${ }^{7}$

with early pneumonia and the varying effect of dexamethasone on different days of illness of COVID-19 in the RECOVERY trial suggest the need for different treatment strategies at different clinical stages of COVID-19 infection. Our results support the hypothesis that control of both viral replication and inflammatory response is important in treatment of early COVID-19 pneumonia. ${ }^{5}$

Our study has several limitations. Without a placebo arm, we are unable to conclude if the protective effect observed in our study was directly due to corticosteroids alone or in combination with a treatment agent, mostly $\mathrm{HCQ}$. Non-randomized treatment selection and small sample size could have biased estimates and limit our subgroup analysis. The estimates in weighted regression are dependent on balancing of 
medRxiv preprint doi: https://doi.org/10.1101/2020.07.18.20157008; this version posted July 21,2020 . The copyright holder for this preprint (which was not certified by peer review) is the author/funder, who has granted medRxiv a license to display the preprint in perpetuity.

It is made available under a CC-BY-NC-ND 4.0 International license .

278 Despite non-parametric method of covariate balancing, there were some imbalances

279 that required further covariate adjustment in regression models. Our estimates could

280 subject to possible model misspecification and are based on assumption that all

281 confounders are controlled. In a conservative view, estimates in unadjusted cox

regression did not show an increased risk of composite outcomes despite seemingly

more severe disease in group that received adjunctive corticosteroids. Having said

that, risk of secondary infection and other adverse outcomes associated with

corticosteroids were not evaluated.

Our analysis could not account for change in clinical practice and experience gained

in managing COVID-19 over time that might affect better outcome in the later stage.

However, it is unlikely to account for lower risk of clinical progression of requiring

oxygen in those with pneumonia on adjunctive corticosteroids.

Lastly, younger population in our cohort and single center design may limit

generalizability of these results to other populations.

In summary, our study shows that the use of adjunctive corticosteroids was associated with lower risk of clinical progression and invasive MV or death, especially in those with pneumonia. Patients in early phase of COVID-19 pneumonia may benefit from adjunctive corticosteroid therapy. Further prospective studies are required to evaluate the clinical efficacy of a combination treatment with antivirals and anti-inflammatory agents in early COVID 19 pneumonia. 
medRxiv preprint doi: https://doi.org/10.1101/2020.07.18.20157008; this version posted July 21,2020 . The copyright holder for this preprint (which was not certified by peer review) is the author/funder, who has granted medRxiv a license to display the preprint in perpetuity. It is made available under a CC-BY-NC-ND 4.0 International license

1. Rothe C, Schunk M, Sothmann P, et al. Transmission of 2019-nCoV infection from an asymptomatic contact in Germany. N Engl J Med 2020;382:970-971.

307

2. Guan WJ, Ni ZY, Hu Y, et al. Clinical Characteristics of Coronavirus Disease 2019 in China. N Engl J Med 2020;382:1708-20.

3. Wang D, Hu B, Hu C, et al. Clinical Characteristics of 138 Hospitalized Patients With 2019 Novel Coronavirus-Infected Pneumonia in Wuhan, China. JAMA 2020.

4. Pedersen SF, Ho YC. SARS-CoV-2: a storm is raging. J Clin Invest. 2020;130(5):2202-2205.

5. Siddiqi HK, Mehra MR. COVID-19 illness in native and immunosuppressed states: A clinical-therapeutic staging proposal. J Heart Lung Transplant. 2020;39(5):405-407.

6. Mehta P, McAuley DF, Brown M, et al. COVID-19: consider cytokine storm syndromes and immunosuppression. Lancet. 2020;395(10229):1033-1034.

7. Guaraldi G, Meschiari M, Cozzi-Lepri A, et al. Tocilizumab in patients with severe COVID-19: a retrospective cohort study. Lancet Rheumatol 2020; published online June 24. https://doi.org/10.1016/S2665-9913(20)30173-9

8. The RECOVERY Collaborative Group. Dexamethasone in hospitalized patients with Covid-19 — preliminary report. N Engl J Med. 2020. DOI: 10.1056/NEJMoa2021436. 
medRxiv preprint doi: https://doi.org/10.1101/2020.07.18.20157008; this version posted July 21 , 2020. The copyright holder for this preprint (which was not certified by peer review) is the author/funder, who has granted medRxiv a license to display the preprint in perpetuity.

It is made available under a CC-BY-NC-ND 4.0 International license .

9. Huang C, Wang Y, Li X, et al. Clinical features of patients infected with 2019 novel coronavirus in Wuhan, China. Lancet 2020; 395: 497-506.

10. Zhou F, Yu T, Du R, et al. Clinical course and risk factors for mortality of adult inpatients with COVID-19 in Wuhan, China: a retrospective cohort study. Lancet. 2020;395(10229):1054-1062.

11. Wu C, Chen X, Cai Y, et al. Risk factors associated with acute respiratory distress syndrome and death in patients with coronavirus disease 2019 pneumonia in Wuhan,

12. Luo P, Liu Y, Qiu L, Liu X, Liu D, Li J. Tocilizumab treatment in COVID-19: A single center experience. J Med Virol. 2020;92(7):814-818.

13. Hainmueller J. Entropy Balancing for Causal Effects: A Multivariate Reweighting Method to Produce Balanced Samples in Observational Studies. Political Analysis.

14. van Buuren S, Groothuis-Oudshoorn K (2011). mice: Multivariate Imputation by Chained Equations in R. Journal of Statistical Software, 45(3),1-67.

15. Greifer, N. cobalt: Covariate Balance Tables and Plots. R package version 4.2.2 (2020) 
medRxiv preprint doi: https://doi.org/10.1101/2020.07.18.20157008; this version posted July 21,2020 . The copyright holder for this preprint

(which was not certified by peer review) is the author/funder, who has granted medRxiv a license to display the preprint in perpetuity.

It is made available under a CC-BY-NC-ND 4.0 International license.

357

358

359

360

361

362

363

364

365

366

367

368

369

370

371

372

373

374

375

376

377

378

379

380

381

382
17. Russell CD, Millar JE, Baillie, JK. Clinical evidence does not support corticosteroid treatment for 2019-nCoV lung injury. Lancet. 2020;395(10223):473-475.

18. Liu, J., Cao, R., Xu, M. et al. Hydroxychloroquine, a less toxic derivative of chloroquine, is effective in inhibiting SARS-CoV-2 infection in vitro. Cell Discov. 2020;6:16.

19. Horby P, Mafham M, Linsell L, et al. Effect of Hydroxychloroquine in Hospitalized Patients with COVID-19: Preliminary results from a multi-centre, randomized, controlled trial. medRxiv 2020. Available at: https://www.medrxiv.org/content/10.1101/2020.07.15.20151852v1

20. Gagnon S, Boota AM , Fischl MA , e t al. Corticosteroids as adjunctive therapy for severe Pneumocystis carinii pneumonia in the acquired immunodeficiency syndrome: a double-blind, placebo-controlled trial. N Eng J Med 1990; 323:1444-1450 
medRxiv preprint doi: https://doi.org/10.1101/2020.07.18.20157008; this version posted July 21,2020 . The copyright holder for this preprint (which was not certified by peer review) is the author/funder, who has granted medRxiv a license to display the preprint in perpetuity.

Table and figures

385

386

387

388

Figure 1: Overview of patients included in the study cohort

389

390

391

392

393

394

395

396

397

398

399

400

401

402

403

404

405

406

407

408

409

410

411

412

413

414

415

416

417

418

419

420

421

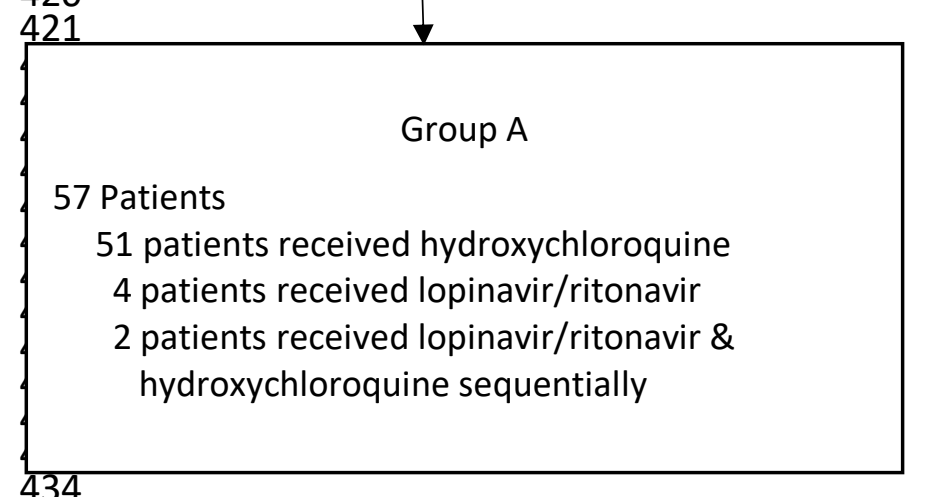

1046 were patients admitted with

COVID-19

94 patients received COVID-19

treatment

952 patients were excluded

945 patients received supportive care

7 admitted for non-respiratory illness

Excluded 2 patients who were on invasive mechanical ventilation prior to initiation of COVID-19 treatment

35 Patients

34 patients received hydroxychloroquine \& corticosteroids

1 patient received lopinavir/ritonavir \& corticosteroids 
medRxiv preprint doi: https://doi.org/10.1101/2020.07.18.20157008; this version posted July 21,2020 . The copyright holder for this preprint (which was not certified by peer review) is the author/funder, who has granted medRxiv a license to display the preprint in perpetuity.

447 Table 1: Baseline characteristics of overall cohort by treatment group

\begin{tabular}{|c|c|c|c|}
\hline & $\begin{array}{l}\text { Group A } \\
\mathrm{N}=57(\%)\end{array}$ & $\begin{array}{l}\text { Group B } \\
\mathrm{N}=35(\%)\end{array}$ & P-value \\
\hline Age (year) & $50(36-58)$ & $48(41-57)$ & 0.94 \\
\hline Female & $12(21 \%)$ & $4(11 \%)$ & 0.24 \\
\hline Ethnicity & & & 0.10 \\
\hline Chinese & $12(21 \%)$ & $14(40 \%)$ & \\
\hline Malay & $10(18 \%)$ & $1(3 \%)$ & \\
\hline Indian & $17(30 \%)$ & $8(23 \%)$ & \\
\hline Others & $18(31 \%)$ & $12(34 \%)$ & \\
\hline Body mass index $\left(\mathrm{kg} / \mathrm{m}^{2}\right)$ & $25.5(23.4-28.4)$ & $25.6(21.7-26.7)$ & 0.40 \\
\hline Comorbidity present & $26(46 \%)$ & $21(60 \%)$ & 0.18 \\
\hline Diabetes mellitus & $14(25 \%)$ & $14(40 \%)$ & 0.12 \\
\hline Hypertension & $16(28 \%)$ & $6(17 \%)$ & 0.23 \\
\hline Hyperlipidaemia & $7(12 \%)$ & $3(9 \%)$ & 0.58 \\
\hline Renal diseases & $10(18 \%)$ & $5(14 \%)$ & 0.68 \\
\hline Cardiac diseases & $3(5 \%)$ & $2(6 \%)$ & 0.93 \\
\hline Neurological diseases & $0(0 \%)$ & $1(3 \%)$ & 0.20 \\
\hline Rheumatologic diseases & $2(4 \%)$ & $1(3 \%)$ & 0.86 \\
\hline Respiratory diseases & $1(2 \%)$ & $1(3 \%)$ & 0.72 \\
\hline Day of Illness* & $4(2,6)$ & $5(4,9)$ & 0.064 \\
\hline Clinical Stage upon treatment & & & $<0.001$ \\
\hline Stage 1 & $40(70 \%)$ & $8(23 \%)$ & \\
\hline Stage 2 & $13(23 \%)$ & $18(51 \%)$ & \\
\hline Stage 3 & $4(7 \%)$ & $9(26 \%)$ & \\
\hline Max Temperature $\left({ }^{\circ} \mathrm{C}\right)^{\star *}$ & $38.5(38.1-39.1)$ & $38.8(38.4-39.3)$ & 0.06 \\
\hline $\begin{array}{l}\text { Use of antibiotics before } \\
\text { treatment }\end{array}$ & $14(25 \%)$ & $20(57 \%)$ & 0.002 \\
\hline Use of inotropes & $2(4 \%)$ & $0(0 \%)$ & 0.26 \\
\hline Use of tocilizumab & $3(5 \%)$ & $5(14 \%)$ & 0.14 \\
\hline C-reactive protein (mg/L) & $12.7(6.2-33.9)$ & $60.7(37.9-109.3)$ & $<0.001$ \\
\hline Procalcitonin (ng/mL) & $0.10(0.06-0.15)$ & $0.13(0.08-0.27)$ & 0.039 \\
\hline White blood cells (x109/L) & $5.5(4.6-6.9)$ & $6.3(4.1,8.9)$ & 0.27 \\
\hline Lymphocytes (x109/L) & $1.2(0.9-1.6)$ & $1.2(0.9-1.6)$ & 0.95 \\
\hline Neutrophils $\left(x 10^{9} / \mathrm{L}\right)$ & $3.7(2.6-4.8)$ & $4.7(2.9-6.4)$ & 0.05 \\
\hline Monocytes $\left(\times 10^{9} / \mathrm{L}\right)$ & $0.51(0.36-0.83)$ & $0.37(0.27-0.51)$ & 0.004 \\
\hline Creatinine (umol/L) & $84(73-94)$ & $74(67-87)$ & 0.06 \\
\hline Bicarbonate (mmol/L) & $24(23-26)$ & $24(23-25)$ & 0.54 \\
\hline Aspartate aminotransferase (U/L) & $30(21-37)$ & $33(23-44)$ & 0.24 \\
\hline Alanine aminotransferase $(\mathrm{U} / \mathrm{L})$ & $28(22-37)$ & $32(20-41)$ & 0.63 \\
\hline
\end{tabular}

Data are median (IQR) or $n(\%)$ unless otherwise stated. $P$ values were calculated using Mann-Whitney $U$ test and $\mathrm{x} 2$ test or Fisher's exact test as appropriate.

${ }^{*}$ Day of illness represent the number of day of illness by symptoms on the day of treatment initiation.

${ }^{* *}$ Max temperature is the highest recorded body temperature on the day of treatment initiation. 
medRxiv preprint doi: https://doi.org/10.1101/2020.07.18.20157008; this version posted July 21,2020 . The copyright holder for this preprint (which was not certified by peer review) is the author/funder, who has granted medRxiv a license to display the preprint in perpetuity.

It is made available under a CC-BY-NC-ND 4.0 International license.

Figure 2. Adjusted and unadjusted covariate balance in overall cohort(a) and in subgroup

465 with pneumonia(b) between two treatment groups.

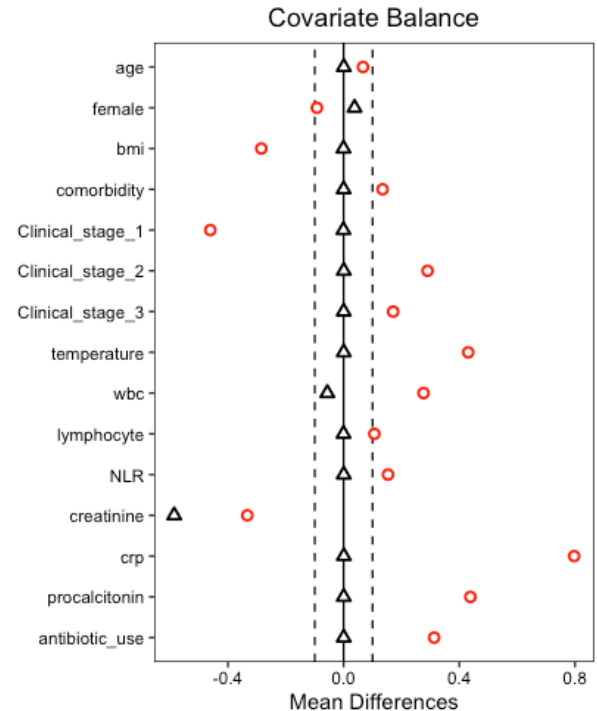

a.

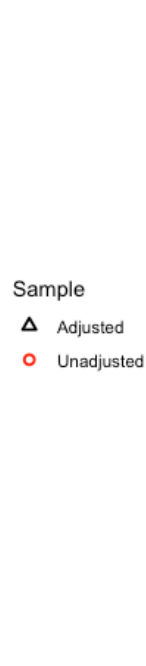

$\Delta$ Adjusted

Unadjusted

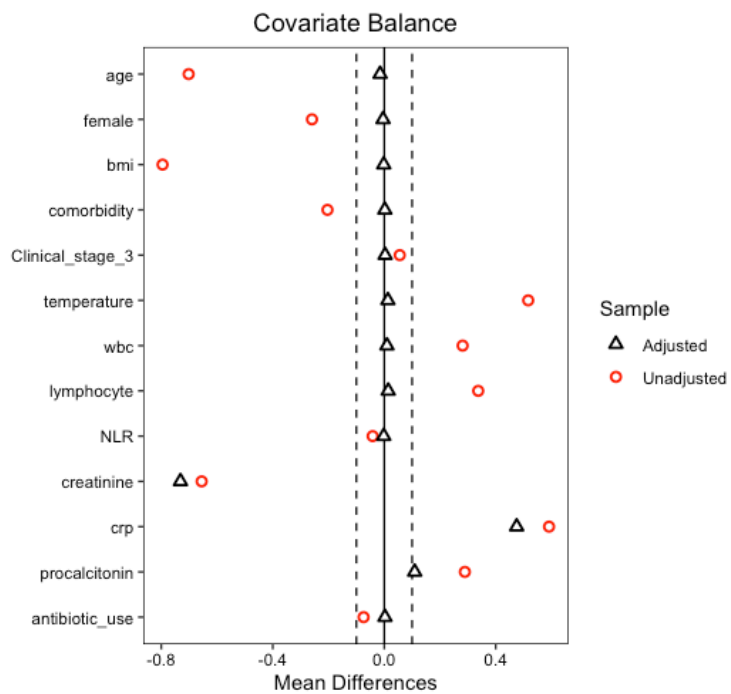

B.

Temperature is the highest recorded body temperature on the day of treatment initiation. bmi, body mass index; wbc, white blood cells; NLR, neutrophil-lymphocyte ratio; CRP, C-reactive protein. 
medRxiv preprint doi: https://doi.org/10.1101/2020.07.18.20157008; this version posted July 21,2020 . The copyright holder for this preprint (which was not certified by peer review) is the author/funder, who has granted medRxiv a license to display the preprint in perpetuity. It is made available under a CC-BY-NC-ND 4.0 International license .

505

506

507

508

509

510

511

512

513

514

515

516

517

518

519

520

521

522

523

524

525

526

527

528

529

530

531

532

533

534

535

536

537

538

539

540

541

542

543

544

545

546

547

548

549

550
Table 3. Unadjusted and adjusted relative hazards of clinical progression and Invasive mechanical ventilation

\section{Clinical Progression}

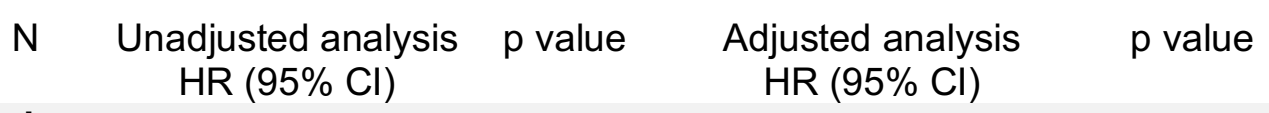
Overall 92
$0.46(0.15-1.40) \quad 0.169$
$0.08(0.01-0.99) \quad 0.049$
$0.13(0.04-0.48) \quad 0.002$
$0.15(0.06-0.39)$
$<0.001$

Pneumonia 44

\section{Invasive Mechanical Ventilation}

$\begin{array}{llllll}\text { Overall } & 92 & 0.88(0.26-3.02) & 0.844 & 0.22(0.02-2.54) & 0.22 \\ \text { eumonia } & 44 & 0.22(0.06-0.85) & 0.028 & 0.30(0.10-0.87) & 0.029\end{array}$

$\mathrm{N}$, number; HR, hazard ratio; $\mathrm{Cl}$, confidence interval.

For adjusted HR in overall group, age, C-reactive protein, procalcitonin were adjusted using weighted Cox regression analysis.

For adjusted HR in pneumonia, age, C-reactive protein, procalcitonin and neutrophil-lymphocyte ratio were adjusted using weighted Cox regression analysis. 
medRxiv preprint doi: https://doi.org/10.1101/2020.07.18.20157008; this version posted July 21,2020 . The copyright holder for this preprint (which was not certified by peer review) is the author/funder, who has granted medRxiv a license to display the preprint in perpetuity.

It is made available under a CC-BY-NC-ND 4.0 International license

551

552

553

Figure 3: Trends of fever and changes of C-reactive protein level by treatment groups.

(a)

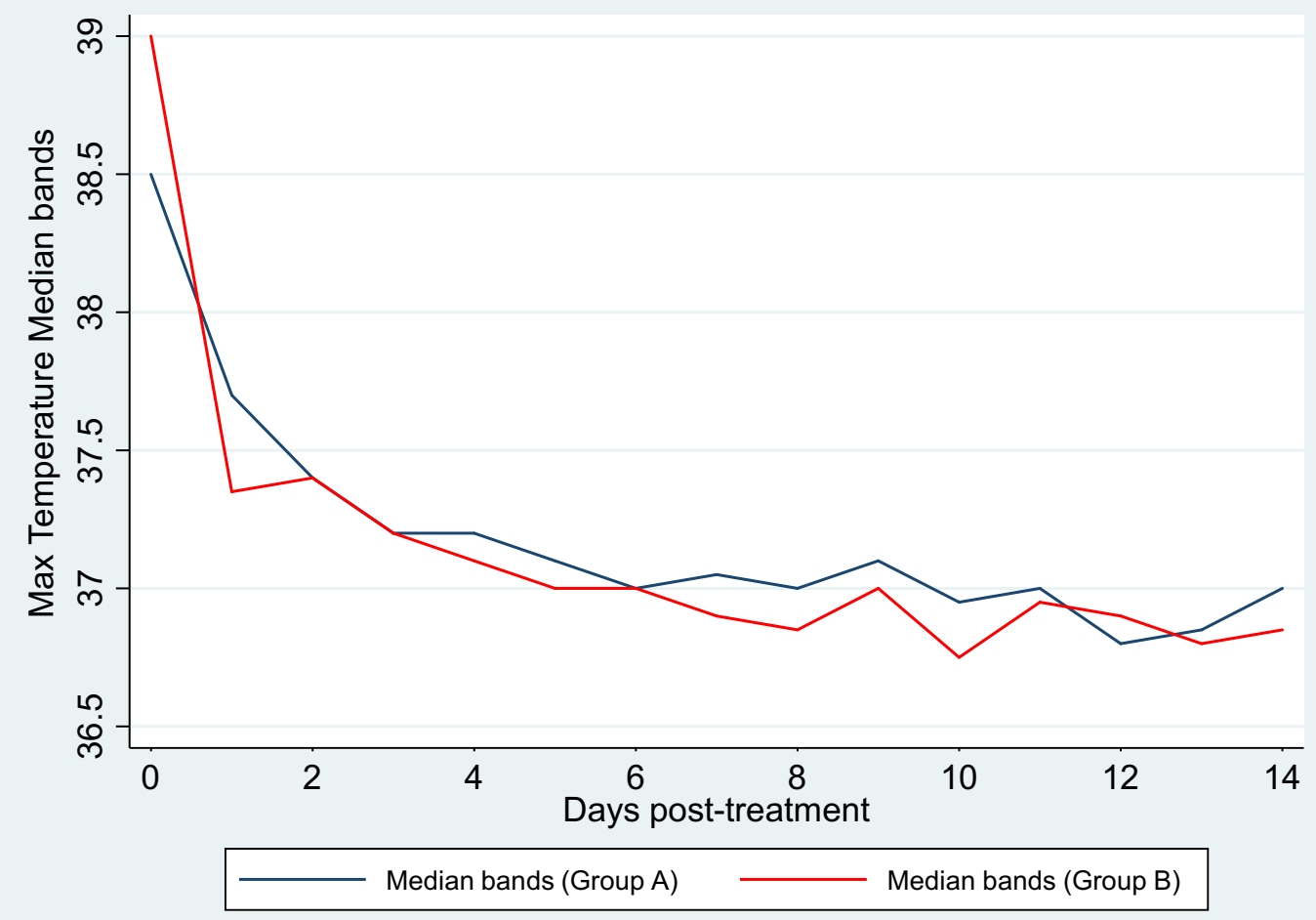

(b)

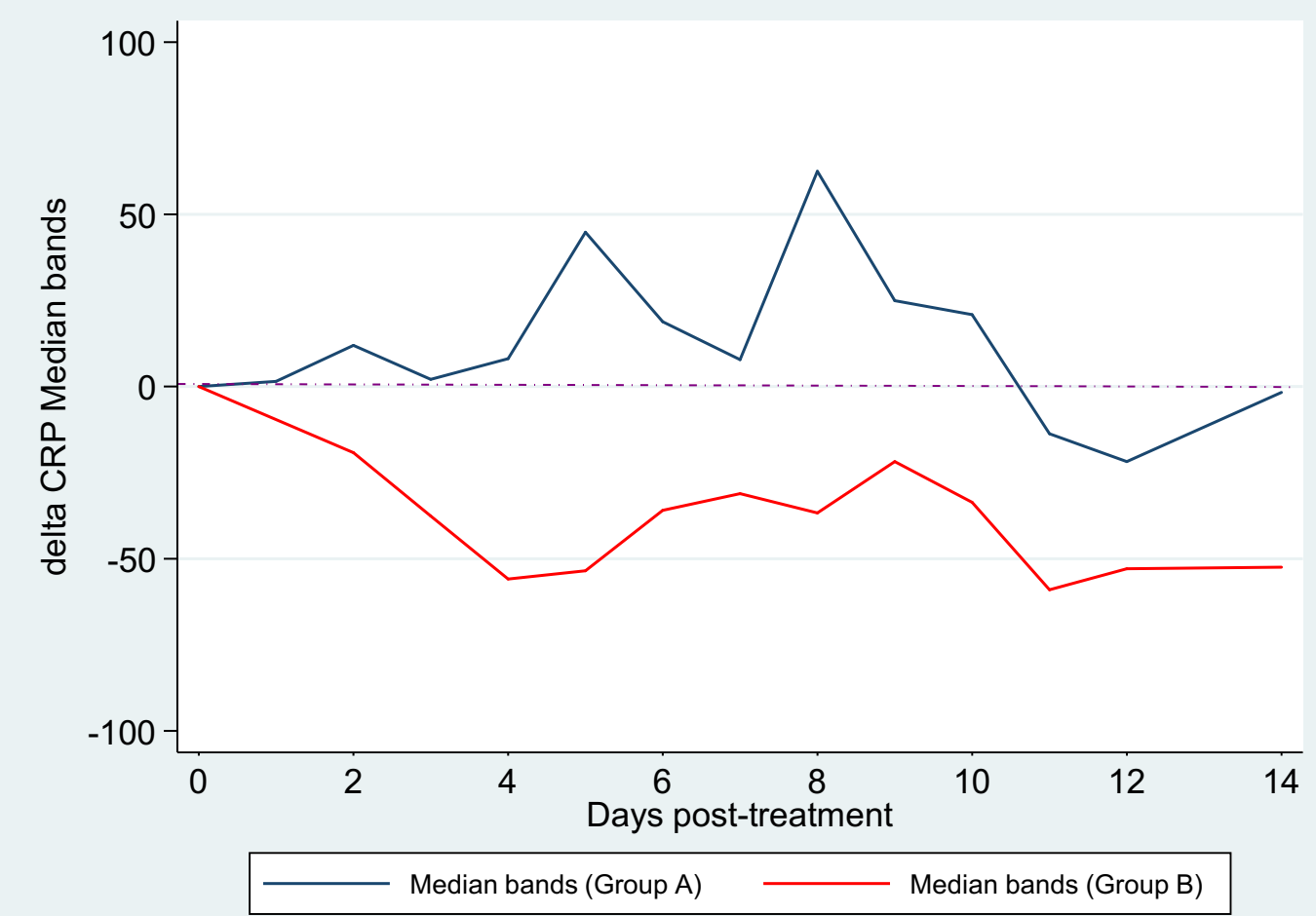

Note: delta C-reactive protein (CRP) is the changes in CRP level following initiation of treatment were calculated compared to baseline CRP level at initiation of treatment 
medRxiv preprint doi: https://doi.org/10.1101/2020.07.18.20157008; this version posted July 21,2020 . The copyright holder for this preprint (which was not certified by peer review) is the author/funder, who has granted medRxiv a license to display the preprint in perpetuity.

It is made available under a CC-BY-NC-ND 4.0 International license .

Figure 4. Kaplan-Meier estimates of the cumulative probability of clinical progression and mechanical ventilation or death by treatment group.

Overall + Group A + Group B

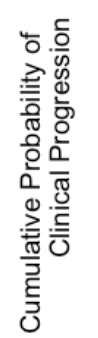

570

572

573

574

Number at risk

Number at risk
Overall
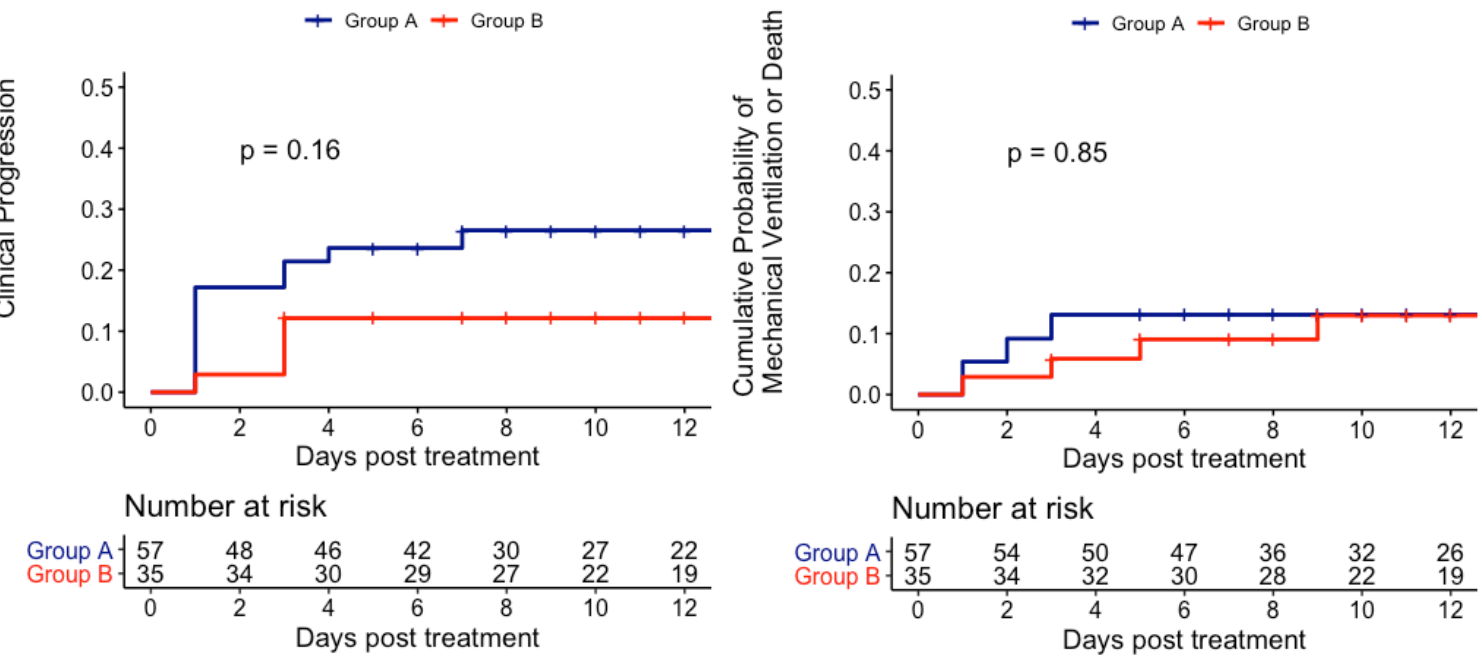

Pneumonia
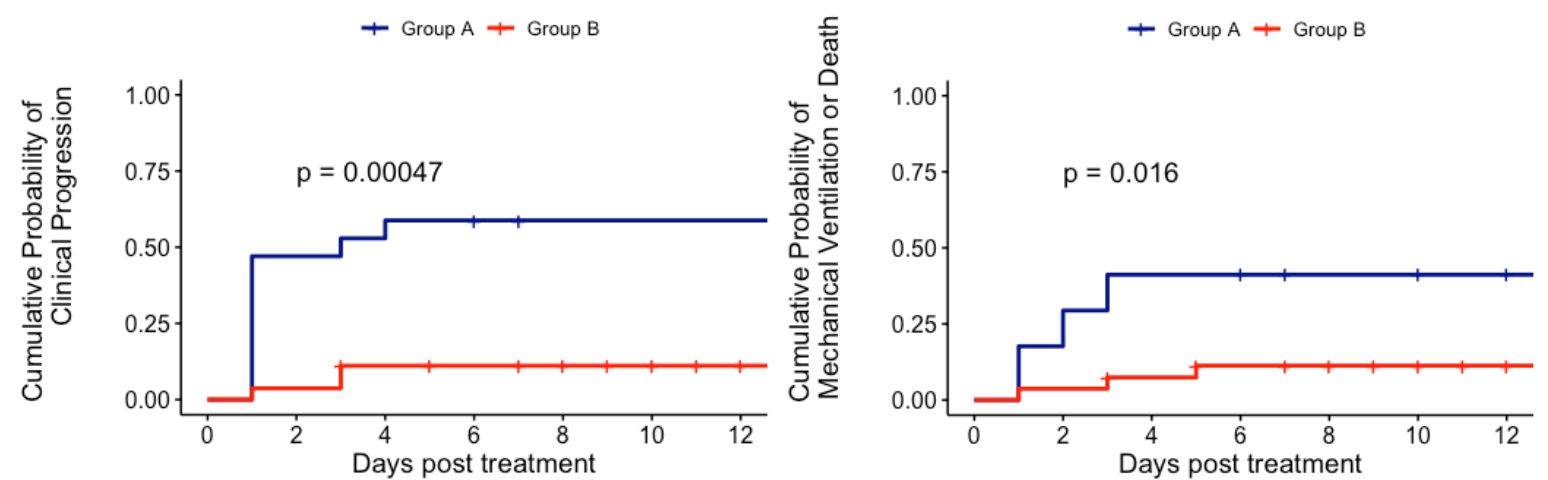

Number at risk
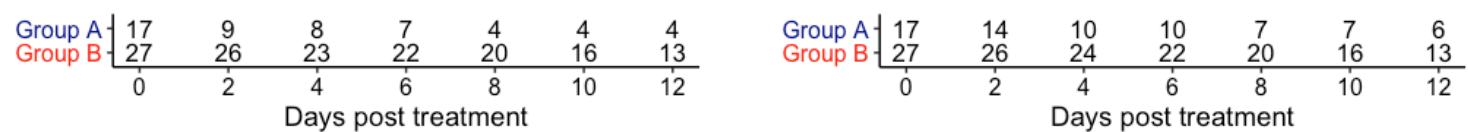
medRxiv preprint doi: https://doi.org/10.1101/2020.07.18.20157008; this version posted July 21 , 2020. The copyright holder for this preprint (which was not certified by peer review) is the author/funder, who has granted medRxiv a license to display the preprint in perpetuity.

Supplementary Material

Table S1a. Covariate balance of the overall cohort between two treatment groups

\begin{tabular}{llcccc}
\hline Covariate & Type & $\begin{array}{c}\text { Unadjusted } \\
\text { difference* }\end{array}$ & $\begin{array}{c}\text { Unadjusted } \\
\text { Variance Ratio }\end{array}$ & $\begin{array}{c}\text { Adjusted } \\
\text { difference* }\end{array}$ & $\begin{array}{c}\text { Adjusted } \\
\text { Variance Ratio }\end{array}$ \\
\hline Age & Continuous & 0.0668 & 0.8349 & 0.0005 & 0.351 \\
\hline Female & Binary & -0.0926 & NA & 0.0376 & NA \\
\hline BMI & Continuous & -0.2848 & 0.6576 & -0.0005 & 0.9822 \\
\hline Comorbidity & Binary & 0.1345 & NA & -0.0001 & NA \\
Stage_1 & Binary & -0.4611 & NA & -0.0007 & NA \\
\hline Stage 2 & Binary & 0.2901 & NA & 0.0005 & NA \\
Stage 3 & Binary & 0.1709 & NA & 0.0002 & NA \\
\hline Temperature** & Continuous & 0.4306 & 0.8152 & 0.0003 & 0.6452 \\
\hline White cells & Continuous & 0.2761 & 1.7111 & -0.0565 & 1.8464 \\
\hline Lymphocytes & Continuous & 0.1061 & 1.5234 & -0.0005 & 1.8224 \\
\hline Neutrophils- & Continuous & 0.1533 & 1.1089 & 0.0004 & 1.4704 \\
lymphocyte ratio & Continuous & -0.3333 & 0.8675 & -0.5859 & 0.6754 \\
\hline Creatinine & Continuous & 0.7969 & 2.304 & 0.0007 & 0.5673 \\
\hline C-reactive protein & Continuous & 0.4382 & 8.9343 & 0.0003 & 2.8179 \\
\hline Procalcitonin & Binary & 0.3128 & NA & 0.0003 & NA \\
\hline Antibiotic use & & & & & \\
\hline
\end{tabular}

Table S1b. Covariate balance of subgroup with pneumonia between two treatment groups

*Standardized mean difference

${ }^{* *}$ Highest temperature recorded on the day of treatment initiation

NA is non-applicable

602

\begin{tabular}{llcccc}
\hline Covariate & Type & $\begin{array}{c}\text { Unadjusted } \\
\text { difference* }\end{array}$ & $\begin{array}{c}\text { Unadjusted } \\
\text { Variance } \\
\text { Ratio }\end{array}$ & $\begin{array}{c}\text { Adjusted } \\
\text { difference* }\end{array}$ & $\begin{array}{c}\text { Adjusted } \\
\text { Variance Ratio }\end{array}$ \\
\hline Age & Continuous & -0.7017 & 1.6742 & -0.0149 & 2.0342 \\
\hline Female & Binary & -0.2593 & NA & -0.0043 & NA \\
\hline BMI & Continuous & -0.7953 & 0.6944 & -0.0018 & 0.9756 \\
\hline Comorbidity & Binary & -0.2037 & NA & 0.002 & NA \\
\hline Stage_1 & Binary & -0.0556 & NA & -0.0031 & NA \\
\hline Stage 2 & Binary & 0.0926 & NA & -0.0012 & NA \\
\hline Stage 3 & Binary & -0.037 & NA & 0.0043 & NA \\
\hline Temperature** & Continuous & 0.5164 & 0.866 & 0.013 & 0.719 \\
\hline WBC & Continuous & 0.2812 & 1.1032 & 0.0097 & 0.574 \\
\hline Lymphocytes & Continuous & 0.3371 & 1.8044 & 0.0143 & 1.8283 \\
\hline Neutrophils- & Continuous & -0.0416 & 0.3842 & -0.0019 & 0.2974 \\
lymphocyte ratio & Continuous & -0.655 & 0.3425 & -0.7311 & 0.2618 \\
\hline Creatinine & Continuous & 0.5912 & 2.5667 & 0.475 & 1.6594 \\
\hline CRP & Continuous & 0.2891 & 5.1193 & 0.1091 & 4.1444 \\
\hline Procalcitonin & Binary & -0.0741 & NA & 0.0025 & NA \\
\hline Antibiotic use & & & & & \\
\hline
\end{tabular}


medRxiv preprint doi: https://doi.org/10.1101/2020.07.18.20157008; this version posted July 21,2020 . The copyright holder for this preprint (which was not certified by peer review) is the author/funder, who has granted medRxiv a license to display the preprint in perpetuity.

It is made available under a CC-BY-NC-ND 4.0 International license.

611 Table S2. Composite outcomes by clinical stages and treatment groups

612

\begin{tabular}{lcccccc} 
Composite of & \multicolumn{2}{c}{ Stage 1 } & \multicolumn{2}{c}{ Stage 2 } & \multicolumn{2}{c}{ Stage 3 } \\
Clinical & $\begin{array}{c}\text { Group A } \\
(\mathrm{n}=40)\end{array}$ & $\begin{array}{c}\text { Group B } \\
(\mathrm{n}=8)\end{array}$ & $\begin{array}{c}\text { Group A } \\
(\mathrm{n}=13)\end{array}$ & $\begin{array}{c}\text { Group B } \\
(\mathrm{n}=18)\end{array}$ & $\begin{array}{c}\text { Group A } \\
(\mathrm{n}=4)\end{array}$ & $\begin{array}{c}\text { Group B } \\
(\mathrm{n}=9)\end{array}$ \\
progression & $3(7.5 \%)$ & $1(12.5 \%)$ & $7(53.8 \%)$ & $1(5.6 \%)$ & NA & NA \\
$\begin{array}{l}\text { Supplemental } \\
\text { oxygen only }\end{array}$ & $0(0 \%)$ & $1(12.5 \%)$ & $4(30.8 \%)$ & $1(5.6 \%)$ & $3(75 \%)$ & $2(22.2 \%)$ \\
$\begin{array}{l}\text { Invasive mechanical } \\
\text { ventilation }\end{array}$ & 0 & & & &
\end{tabular}

613

614 Stage 1, no pneumonia; Stage 2, pneumonia with no supplemental oxygen; Stage 3, pneumonia on

615 supplemental oxygen 